\title{
Legen som sakkyndig - rollen og historien
}

\author{
Sakkyndighetsordningen har århundrelange tradisjoner i norsk rett. Men det var først med straffeprosess- \\ loven av 1887 at dagens praksis ble etablert, og at psykiatrien for alvor kom inn. Legens posisjon i retten har \\ alltid vært problematisk. Fra en tradisjonelt sett autonom rolle, forankret i biomedisinen, skal legen «tjene» \\ en autoritet basert på andre normer og et annet samfunnsoppdrag.
}

Det kan være en utakknemlig oppgave å være rettsmedisinsk sakkyndig i straffesaker som har stor offentlig interesse. Psykiaterne Torgeir Husby og Synne Sørheim kunne neppe forutse det hardkjøret de er blitt utsatt for etter å ha levert sakkyndighetserklæringen om Anders Behring Breiviks mentale tilstand i forbindelse med terrorhandlingene 22. juli 2011. I lang tid har det haglet med beskyldninger om inkompetanse og slett utført arbeid, basert på et mer eller mindre kvalifisert grunnlag. Ulike grupper har deltatt i debatten: journalister, filosofer, historikere, psykologer, samfunnsvitere m.fl. Men kanskje mest påfallende er det at flere av de kritiske røstene kommer fra psykiaternes egne rekker. Dette er oppsiktsvekkende i lys av at legeprofesjonen generelt er preget av sterk kollegialitet og streng yrkesjustis - konflikter rundt faglig uenighet skal og bør tas opp internt.

«Det er et velkjent faktum, at det er meget vanskelig å få en medisiner til å desavouere en kollega,» hevdet stortingsrepresentant Christian Stray (1894-1981) i 1934 da han talte for å få oppnevnt en uhildet rettsmedisinsk kommisjon som kunne granske den såkalte Helte-saken på nytt (1). Denne saken, som pågikk i 40 år (1906-46), var trolig 1900 -tallets største justismord. Det var de rettsoppnevnte legenes rapport som i 1907 bidro til å felle de tiltalte for drap. Den gang var det ikke snakk om rettspsykiatri, men rettspatologi - et fag med grunnlag $\mathrm{i}$ «eksakt» vitenskap. Saken utviklet seg nærmest til en rettsmedisinsk slagmark (2).

Det finnes også andre eksempler på straffesaker der kollegiale normer brytes. Fra nyere tid er Liland-saken og Torgersensaken de mest opplagte. Hvorfor er det slik? Hvorfor brytes profesjonens normer i rettssaker med stor offentlig interesse? Noe av forklaringen kan vi muligens finne i den historiske bakgrunnen for etableringen av sakkyndighetsvesenet og i forholdet mellom to hegemoniske og kulturelt sett svært ulike profesjoner - den medisinske og den juridiske.

\section{Lemfeldig, ukyndig og subjektiv}

Sakkyndighetsordningen har røtter langt tilbake i historien, i Danmark-Norge fra 1600-tallet. Medisinen var faktisk det første ekspertområdet som ble benyttet i større utstrekning i strafferettspleien. Ut fra tradisjon har således legene fått en relativt sterk posisjon i rettsapparatet (3). Men sakkyn- digheten var først og fremst knyttet til de «harde» fagene, til anatomi, patologi, toksikologi m.fl. Psykiatrien kom for alvor inn først mot slutten av 1800-tallet, med straffeprosessloven av 1887 (også kalt juryloven, fordi den etablerte juryordningen og dermed lekmannsprinsippet i straffesaker).

Med denne loven ble også den «muntlige rettergangen» innført. Det innebar at legen pliktet både å fremstå som vitne, dvs.

å fremskaffe fakta, og å gjøre tjeneste som sakkyndig, dvs. å gi skjønnsmessige vurderinger til retten. Dette skulle primært skje skriftlig, om ønskelig også muntlig. Det ble presisert at den sakkyndiges erklæring ikke var bindende for retten, men likevel av vesentlig betydning. Dermed ble de rettsmedisinsk sakkyndige tillagt en innflytelse på sakens utfall som mer enn tidligere nødvendiggjorde «en betryggende ordning af deres virksomhet», som Francis Hagerup mulighet til å styrke både subprofesjonens faglige kvalifikasjoner og dens status og posisjon. Winge, som i 1896 tok doktorgraden med avhandlingen Den retsmedicinske undersøgelse af den sindssyge lovovertrceder (6), arbeidet iherdig med dette for øye. Blant de sakene han brant for og som han fikk juristene med på, var å få etablert en rettsmedisinsk kommisjon som både skulle ha en rådgivende og en kvalitetssikrende funksjon. Den skulle bekles av profesjonens egne, men med representanter for ulike spesialområder. Han fikk gjennomslag i $1900(3,5)$.

\section{Jus over medisin}

Under debatten om disse spørsmålene kom juristenes overlegenhet i forhold til legene ofte til uttrykk. Ledende jurister ga klar beskjed om hvilken rolle legene skulle spille i rettsapparatet. Legens oppgave var

\section{«I retten må legen forholde seg til en autoritet som representerer en annen kultur og har et annet samfunnsoppdrag»}

(1853-1921), en av arkitektene bak loven, formulerte det (4). Men var legene beredt til å påta seg denne nye og mer omfattende oppgaven?

1898 påpekte statsadvokat Peder Kjerschow (1857-1944), en av nestorene i det juridiske miljø, at det hadde vært en vanskelig tid etter at juryloven hadde trådt i kraft i 1890 - og en «Overraskelsestid, ikke minst for Lægen» (5). Det nye for legen var for det første erkjennelsen av at hans rettsmedisinske innsikt ofte ikke strakk til, for det andre forståelsen av at hans vitenskap kunne spille en avgjørende rolle i retten - ikke minst $\mathrm{i}$ «de alvorligste kriminelle Dramaer».

I særlig grad rettet juristene oppmerksomheten mot rettspsykiatrien, som etter deres mening var svak og spekulativ. Lemfeldig, ukyndig og subjektiv var ord som ble benyttet om selve virksomheten. Så hadde da også en av tidens mest toneangivende sinnssykeleger tatt affære. Politilege og psykiater Paul E. Winge (1857-1920) så i straffeprosessloven en å gi premisser for rettens valg. Legen var «tjener» og intet annet, og det for en autoritet større enn hans egen. Generelt advarte juristene mot at retten $\mathrm{i}$ for stor grad underla seg fagekspertenes avgjørelser. Man skal huske på, sa Bernhard Getz (1850-1901), vår første riksadvokat, at systemet bygger på at det ikke er spesialistene eller de sakkyndige som avgjør tingene, «men at de blot udtaler sin Mening og forklarer sig for Domstolen eller Juryen» (5). Det er retten som avgjør. Han ba seg frabedt den fagarroganse man ikke sjelden opplever fra de sakkyndiges side - at de mener at andre «intet forstaar af deres Fag».

Getz ga med andre ord utvetydig beskjed om at i retten er vitenskapen underlagt den rettslige autoritet. Autoritetsforholdet var udiskutabelt. På den annen siden skal vi ikke unnlate å minne om at det ikke så rent sjelden har vært beleilig for juristene å overlate de vanskelige spørsmålene om f.eks. tilregnelighet og særreaksjoner til psykiaterne, og at de i så måte har skjøvet de sakkyndige foran seg $(2,7)$. 
Men siden jusen har prioritet over vitenskapen, historisk og politisk, har dette ofte plassert legen $i$ en lite tilfredsstillende posisjon. Den er vanskelig i lys av legenes tradisjonelt sett autonome stilling og medisinens naturvitenskapelige forankring. I sitt daglige arbeid stiller legene med stor autoritet diagnoser og «avgjør» pasientenes videre skjebne. Det er avgjørelser som sjelden bestrides og som i hovedsak hviler på vitenskapsbasert kunnskap. I retten, med lovfortolkning og presedens som grunnpremiss, stiller det seg annerledes. Her står legene ofte overfor skarpskodde jurister som gjerne betviler deres bevismateriale og konklusjoner - selv om funnene ut fra vitenskapelige kriterier skulle være krystallklare (8).

I Hetle-saken var det over 20 leger som engasjerte seg, også utlendinger, enten fordi de ble bedt om det eller fordi de selv tok initiativ (2). Sammen med en rekke andre, blant dem flere av tidens fremste forfattere (9), var de ivrige deltakere i den offentlige debatt. Gang på gang ble det satt frem beskyldninger mot de sakkyndige - om faglig lemfeldig arbeid, feiltolkinger og inkompetanse. Og gang på gang ble saken forsøkt gjenopptatt. 28 år etter at dom var falt, i 1935, ble det endog oppnevnt en ny rettsmedisinsk kommisjon som fikk i oppdrag å granske saken på nytt. I forkant kranglet man om hvem som skulle sitte der. Det var problematisk å finne leger som ikke sto $i$ et kollegialt eller vennskapelig forhold til hverandre eller som ikke ble beskyldt for å gjøre det. Andre vegret seg fordi de mente at saken var så betent. I pressen var kolleger og andre straks på banen (2).

\section{Profesjonens prestisje og ære}

Profesjonens yrkesjustis om å ta debatten i egne rekker ble den gang som i dag satt til side. Hvorfor? Forklaringen kan dels ligge $i$ at jusen har forrang fremfor medisinen, dels $i$ at legen i rollen som rettsmedisiner ikke er på hjemmebane. I retten må legen forholde seg til en autoritet som representerer en annen kultur og har et annet samfunnsoppdrag. «Retshaandhævelsen er samfundets høieste funksjon,» som legen Johan Scharffenberg (1869-1965) uttrykte det han var blant de mange som engasjerte seg i Hetle-saken (10). I en slik situasjon og i saker med stor publisitet oppstår det gjerne et behov hos enkelte for å overbevise om legestandens kompetanse og dyktighet for slik å bidra til å ivareta profesjonens prestisje og ære. Men fristelsen til å posisjonere seg og påberope seg rollen som forvalter av «den rette lære» er unektelig også til stede. Det gjelder psykiatere så vel som fagfolk fra andre medisinske spesialiteter.

\section{Aina Schiøtz}

aina.schiotz@isf.uib.no

Institutt for samfunnsmedisinske fag

Universitetet i Bergen
Aina Schiøtz (f. 1947) er dr.philos., historiker og professor i medisinsk historie.

Forfatter har fylt ut ICMJE-skjemaet og oppgir ingen interessekonflikter.

Litteratur

1. Hetlesaken blir antagelig gienoptatt (Forhandlinger i Stortinget (nr. 222), 25. mai 1934, s. 1774]. Aftenposten 26.5.1934.

2. Schiøtz A. Hetlesaken - en rettsmedisinsk slagmark. Nytt Norsk Tidsskrift 2006; 23: 331-46.

3. Schiøtz A. Medisin og juss: ambisjoner og ulikheter. Opptakten til den rettsmedisinske kommisjon 1880-1900. I: Benum E, Haave P, Ibsen H et al, red. Den mangfoldige velferden. Festskrift til Anne-Lise Seip. Oslo: Gyldendal Akademisk, 2003.

4. Hagerup F. Den norske Straffeproces paa grundlag af Juryloven almenfattlig fremstillet. Kristiania: Aschehoug, 1890: $21 \mathrm{ff}$.

5. Hagerup F. Forhandlinger ved Den Norske Kriminalistforenings femte møde i marts 1898. Kristiania: Aschehoug, 1898

6. Winge PE. Den retsmedicinske undersøgelse af den sindsyge lovovertræder. Kristiania: Cammermeyer, 1896.

7. Stanghelle H. Sakkyndighetens fallitt. Aftenposten 13.1.2006.

8. Schiøtz A. Den (retts)medisinske sakkyndighet. Rasjonalitetsformer og rolleoppfatninger i medisin og juss. Tidsskrift for Strafferett 2006; 6: 20-38.

9. Kittang A. Hetlesaka og forfattarane. Nytt Norsk Tidsskrift 2006; 23: 347-56.

10. Scharffenberg J. Hetlesaken. Tidsskr Nor Lægeforen 1909; 29: 1067.

Mottatt 23.2. 2012 og godkjent 8.3. 2012. Medisinsk redaktør Erlend Hem. 